DOI 10.31558/2519-2949.2020.4.9

УДК 323/32.019.5/ 659.4

ORCID ID: https://orcid.org/0000-0002-1055-1629

Новицький О. О., Південноукрайнський національний педагогічний

університет ім. К.Д. Уиинського

\title{
КОНЦЕПТИ ЗАСТОСУВАННЯ ПРАЙМІНГУ ТА ТРИГЕРУ ЗМІ В ПОЛІТИЧНОМУ ЖИТТІ
}

Стаття направлена на розгляд та вивчення таких інструментів мас-медіа як праймінг та тригер. Виникає багато питань щодо закономірностей впливу інформаційного масиву на суспільство, на політичне життя. Аналіз представлених в літературі досліджень виявляє, щчо теоретичний науковий інтерес є не досить активним в Украӥні.

Безпосередньо увага стосується застосування ииих засобів в політичному житті, в політичній рекламі тощо. На сучасному етапі модель праймінгу активно використовується в рамках когнітивних досліджень, щзо дає можливість відслідковувати вплив прайму на когнівтину реальність. Це є иікавим та перспективним щодо дослідження локальних ефектів впливу неусвідомлюваної інформачії на ефекти усвідомлення в рамках політичного життя. Однак, до иього часу політична наука не дійшла остаточних висновків щэодо залежності праймінг-ефекту на політичну свідомість, на політичний вибір тощз.

В статті представлене визначення політичного праймінгу та тригеру, обговорюються проблемні питання та установки. Окремо акиентується увага розмежуванні понять «праймінг» та «ефект праймінгу». Визначено, що ефект праймінгу активно діє в політичному житті, зокрема, в політичній рекламі. Практично кожний політичний актор бажає впливати на прочес активації пам'яті вибория. Теорія політичного медіапраймінгу фокусується на те, яким чином індивід сприймає отримувану з медіа політичну інформацію.

Важливим додатковим елементом праймінгового процесу с застосування тригерів. Потреба у введенні тригерів обумовлена необхідністю аналізу подій, які безпосередньо не пов'язані з політикою, але можуть інтерпретуватися в політичному ключі.

Ключові слова: праймінг, тригер, ЗМI, політика, суспільство, політична реклама, політичний праймінг, політичний тригер.

Постановка проблеми у загальному вигляді. Класична модель комунікації передбачає наявність двох акторів: відправника та одержувача інформації. А будь-яка комунікація виступає лише в ролі посередника між ними. Ця модель багато що пояснює, проте не вловлює того, що медіа не лише переносить інформацію, а завжди накладає свій відбиток на сприйняття цієї інформації. Мас-медіа не тільки розважають і освічують. Вони виконують також маніпулятивно-управлінську функцію, вони впливають на наші культурні та соціально-психологічні цінності, змінюють наші установки, моделі поведінки та сприйняття реальності. Формуючи міфи і стереотипи, ЗМІ активно використовують механізм публічного сприйняття. Знання особливостей сприйняття та переробки інформації в пам'яті людини, можна досить ефективно маніпулювати громадською думкою. Когнітивні дослідження в галузі сприйняття мас-медійної інформації направлені на вивчення механізмів пригадування інформації та накопичення ключових медіаконцептів та образів в пам'яті індивідів.

Аналіз останніх досліджень і публікацій. Теоретичний аналіз даної проблематики не досить активний в Україні. Зокрема, є деякі публікації в рамках психології, лінгвістики, журналістики, з аксіології тощо. Наприклад, це аналіз Ю.Шамаєвої, яка здійснила лінгвокогнітивне осмислення проблеми класифікації емоцій через аналіз специфіки феноменів праймінгу та де фокусування [7]. Щодо фундаментальних досліджень, то слід вказати Л.Берковіц, який спеціалізується на проблемах агресивної поведінки [2]; медіа психологія, вплив ЗМІ - Дж.Брайант, С.Томпсон [4 ] ВинтерхоффШпурк П. [5].

Метою статті є: вивчення специфіки застосування праймінгу та тригеру ЗМІ в політичному житті.

(C) Новицький О. О., 2020 
Виклад основного матеріалу. Саме слово «праймінг» (priming) походить від англійського «to prime» (готувати, інструктувати заздалегідь, давати попередню установку і т.п.). Зазвичай «priming» перекладається як підказка, підготовка, ефект передування тощо. Як зазначає О.Харитонов: «..наприкінці XX століття психологи помітили цікаву річ. Коли дві події відбуваються одна за одною, то враження від першої можуть сильно впливати на враження від другої - навіть якщо події логічно між собою не пов'язані. Такий ефект назвали фіксованими установками або «праймінгом» (англ. to prime - інструктувати)» [6].

За одним з визначень, праймінг - це явище імпліцитної пам'яті, яке представляє собою,- або зміну швидкості або точності вирішення задачі (перцептивної, розумової), що спостерігається після представлення інформації, пов'язаної зі змістом чи з контекстом цього завдання, але не співвідноситься прямо з їі метою та вимогами; або це підвищення ймовірності спонтанного відтворення цієї інформації у відповідних умовах.

Згідно з іншим визначенням, праймінг - це несвідома (недекларативно) форма пам'яті, яка полягає в зміні здатності людини ідентифікувати, відтворювати або класифікувати об'єкт в результаті попереднього нагадування про цей або про подібний об'єкт.

Як правильно зазначає Л. Шнуровська «варто розмежувати два поняття: праймінг - факт досвіду попередньої дії, яка вплинула на вирішення актуальної задачі, та праймінг-ефект - якісна (наявність або відсутність) або кількісна (швидкість або точність) зміна параметрів реакції або дії людини у відповідь на появу об'єкта, який частково або повністю є елементом попереднього досвіду» [8, с. 62].

Ефект праймінгу передбачає, що під впливом медіа у реципієнтів формуються асоціації, що мають відношення до медіа-контенту, який був реципієнтами сприйнятий. Ефект праймінгу грунтується на тому, що, чим меншим є у реципієнта інформації безпосередній досвід взаємодій та пізнання об'єкта дійсності, тим більшою є ймовірність, що його уявлення про ці об'єкти будуть формуватися на основі повідомлень мас-медіа.

Праймінг вводить сюди також проблему тимчасового розриву між контактом повідомлення 3 індивідом та пригадуванням. Чим коротший цей розрив між демонстрацією повідомлення, пригадування його теми та іiї використанням у ментальному процесі, тим вищою є ймовірність того, що уявлення споживача щодо цієї теми будуть пов'язані з отриманим повідомленням. Медіаподія викликатиме спогади та певну реакцію людини. До випадків прояву праймінга відноситься копіювання індивідами поведінки героїв на телевізійному екрані. Саме на таких очікуваних ефектах часто грунтуються будь-які заборони. Активовані за допомогою праймінга думки, в свою чергу, активують інші семантично пов'язані думки.

Дуже цікавим для розуміння нашого суспільства є дослідження А.Бандури, який говорить про те, що віра в реальність подій, які ми бачимо у якись фільмах, активно сприяє застосуванню певної поведінки, яку ми бачимо на екрані $[1$, с.680]. Л.Берковіц та Дж.Аліото вивчали ефект праймінгу від жорстоких видів спорту (футбольний матч чи боксерський поєдинок) [ 2].

Ефект праймінгу не є стабільним і залежить не тільки від часу експозиції, але також від індивідуальних особливостей людини та їі сприйняття медіаконтенту. Зокрема, ефект праймінгу посилюється в тих випадках, коли люди певним чином інтерпретують значення медіапродукту (наприклад, фільму); вірять, що існують певні причини, що виправдовують агресивні або жорстокі дії персонажів; ототожнюють себе з героями фільму; вірять, що те, що відбувається на екраніне вигадка, а реальні події; бачать сцени насильства та згадують асоціативні думки або почуття, які відбулися з ними в минулому.

Викладене підкріплюється реальними експериментами різних вчених. Наприклад, ефект віри в реальність того, що відбувається на екрані був доведений Л.Берковіцем та Дж.Аліото на двох групах реципієнтів. Обом групам транслювався один і той же фільм, але одній групі говорили, що фільм заснований на реальних бойових діях, а іншим - що фільм вигаданий. Потім учасникам експерименту видавалися електрошокери, якими вони повинні були покарати кривдників, і перша група демонструвала більшу жорстокість, ніж друга [2].

В основі теорії праймінгу знаходиться модель потрійної взаємозумовленості. Відповідно до цієї моделі, три компоненти пояснюють когнітивні здібності людини: поведінка; когнітивні, біологічні та інші індивідуальні характеристики, та вплив зовнішнього середовища. Ці три компоненти взаємодіють і впливають один на одного на різних рівнях.

Дж.Брайант та С.Томпсон відзначають, що теорія праймінгу виходить 3 трьох моделей роботи людської пам'яті: модель кошика, модель акумуляторної батареї та синаптична модель [4]. Модель кошика передбачає, що пам'ять працює, як велика кошик для сміття: елементи, що знаходяться зверху, 
пригадуються краще, ніж все, що знаходиться знизу. Модель акумуляторної батареї передбачає, що значущим $€$ не час активації (наскільки давно вона сталася), а частота активації (наскільки часто вона відбувається). Тобто, активація діє подібно зарядці акумуляторної батареї (важливим є не час розрядки, а частота підзарядки). Синаптична модель комбінує дві попередні та передбачає, що поняття, яке піддалося праймінгу має більш виражений вплив протягом короткого проміжку часу.

Таким чином, праймінг - це вплив попередньої інформації на активацію специфічних асоціацій в пам'яті без активної участі людини. Він не залежить від намірів людини, здійснює мимовільний та неусвідомлюваний вплив на вирішення завдань. Зміна здатності до опізнання або вилучення інформації про об'єкт відбувається в таких умовах, в яких людина або не усвідомлює зв'язок подій, або не усвідомлює, що перша подія загалом була відсутня. У зв'язку з цим праймінг може вплинути на рішення задачі як позитивно, так і негативно. Відповідно розрізняють позитивний і негативний праймінг. У першому випадку праймінг покращує (прискорює) переробку стимулу, у другому погіршує (уповільнює).

Що стосується застосування праймінгу у політичному житті, то тут сказати, що на сучасному етапі реальність його використання не викликає заперечень. Ще в 2011 році в наукових колах вже йшла мова про його застосування « ... багато наукових підтверджують реальність праймінгу, в тому числі в політичному житті. Як приклад, можна навести ситуацію, коли людина дивиться економічний репортаж - i саме ця інформація є для глядача базовою і первинною. Пізніше цей репортаж гратиме функцію праймінгу, і буде задавати тон подальшій рекламі, в тому числі політичній. Праймінг $\epsilon$ перспективною технологією, адже його спрямування $\epsilon$ стратегічним, і носить конструктивний характер» [3].

Теорія політичного медіапраймінгу фокусується на те, яким чином індивід сприймає отримувану 3 медіа політичну інформацію. Мається на увазі, що ця інформація впливає на індивіда, причому такий вплив є короткостроковим. У цьому є головна відмінність теорії медіапраймінгу від теорії культивації, за допомогою якої вивчаються, головним чином, довгострокові ефекти медіа. Виходить, що ефекти медіа ситуативно обумовлені, оскільки сам медіадискурс є ситуативним.

В рамках теорії політичного праймінгу довгий час вивчалися ефекти, що виражаються через поведінку індивіда. Передбачалося, наприклад, що у разі перегляду передач, в яких чималу роль відіграють різні прояви агресії по відношенню до ідеологічних супротивників, аудиторія буде активувати відповідні асоціативні зв'язки та згодом реалізовувати схожу поведінку. Наприклад, деякі дослідники відзначають, що ті, хто дивиться регулярно телевізійні передачі, «пов'язують 3 показаними політичними проблемами тих політиків і партії, які, на їх думку, більше підходять для вирішення цих проблем. Чим більший інтерес певна політична проблема викликає у публіки, тим серйозніші наслідки для політика, який пов'язаний з цією проблемою» [5, с. 222]. Практично такої ж думки Дж.Брайант та С.Томпсон, які вказують, що «виборці, які проводять багато часу перед телевізором, швидше сприймають медіаобраз кандидатів, ніж їх партійну приналежність» ...[4, с. 113].

Такі результати говорять про те, що ефект праймінгу активно діє в політичному житті, зокрема, в політичній рекламі. Практично кожний політичний актор бажає впливати на процес активації пам'яті виборця. Наприклад, людина попередньо дивиться репортаж з якоїсь економічної проблеми, то в неї виникають відповідні асоціації цього початкового концепту, які активізують інформацію 3 даної теми і вона буде присутня на ближчому до свідомості рівні, ніж будь-яка інша інформація. В такому випадку телевізійний сюжет створюється таким чином, що ця проблема стає важливою, коли вона приєднується до іншої інформації, наприклад до політичного життя, до політичної реклами. В цій моделі або попередня реклама, або репортаж можуть виконувати функцію праймінгу та задавати тональність інтерпретації подальшої реклами. Так, політичного актора, скоріше за все, не задовольнить, якщо його реклама з'являється після репортажу, абсолютно не відноситься до політики. А кандидат, слабкий в економічних питаннях, навряд чи побажає, щоб його реклама йшла після репортажу, в якому наводяться приклади проблем економічного життя.

Важливим додатковим елементом праймінгового процесу $є$ застосування тригерів. Потреба у введенні тригерів обумовлена необхідністю аналізу подій, які безпосередньо не пов'язані 3 політикою, але можуть інтерпретуватися в політичному ключі. Тобто, необхідно описати природу асоціативних зв'язків не з позицій редукції значень або установки семантичних ланцюгів, а з позиції політичної аксіології.

Тригер рухає асоціативний ланцюжок по відношенню до певного знаку-моменту, який потім співвідноситься 3 політичною системою. Це не означає, що ціннісно-політичний тригер не може виступати в якості об'єкта оцінки, різниця лише в тому, що тоді він перестане бути тригером. 
Тригер знаходиться в двох положеннях: оцінюваний тригер вже не є тригером, він стає об'єктом оцінки, а неоцінений тригер залишиться тригером і може запустити ланцюжок асоціативних зв'язків, в результаті чого ми отримаємо оцінку індивідом явищ, більш широких, ніж сам тригер.

Політичний тригер схильний до повторення. він регулярно зустрічається в текстах, що сприяє його фіксації в свідомості індивіда та активації подальшого сценарію. Він повинен бути пізнаваним, інакше активація не відбудеться, і найпростіший спосіб домогтися впізнаваності - повторення його не тільки в рамках одного тексту, а й в сукупності текстів різних тематик, які часом не відносяться безпосередньо до цього політичному тригеру або зовсім до політики.

Висновки. Теорія політичного праймінгу заснована на принципі активації. Саме в ментальній моделі індивіда, який користується ЗМІ, активується не один смисловий вузол, а цілий ланцюжок. У випадку з політичним життям така модель дає можливість говорити про розгортання такого ланцюжка ціннісних та політичних асоціацій. Тригери доповнюють політичний медіапраймінг. Саме він $є$ змінною, яка містить оціночний потенціал. Активуючи оціночні сценарії, тригери стають такою зачіпкою, за яку чіпляється ментальна модель індивіда. Звичайно, у кожного індивіда свій набір ціннісно-політичних тригерів. Це залежить від його особистого досвіду, світогляду і т. д.

Перспективним напрямом подальшого дослідження є більш докладне вивчення політичної частини ментальної моделі індивіда, задля використання в рамках політичного тригеру та праймінгу. Саме ці інструменти створюють відповідні ефекти для забезпечення високої ефективності впливу на суспільство.

\section{Бібліографічний список:}

1. Bandura A., Dorothea Ross, Sheila A. Ross (1961). Впервые опубликовано в Journal of Abnormal and Social Psychology, 63, 575-582.

2. Берковиц Л. Агрессия. Причины, последствия и контроль. М., 2007. 512 с.

3. Біденко А. Технологія праймінгу в дії. Українська правда.Блоги. 26.04.2011. https://blogs.pravda. com.ua/ authors/ bidenko/ 4db6904b57e44/

4. Брайант Дж., Томпсон С. Основы воздействия СМИ.: Пер. с англ.М., 2004. 432 с.

5. Винтерхофф-Шпурк П. Медиапсихология. Основные принципы. Х., 2016, 268 с.

6. Харитонов О. Про ефективний спосіб маніпуляції свідомістю. 30 листопада 2018. https://tokar.ua/read/29332

7. Шамаєва Ю. Праймінг та дефокусування у лингвокогнітивній репрезентації інтерсеміотичного континуума категорії EMOTIONS. Вісник ХНУ імені В. Н. Каразіна. Серія: Іноземна філологія. Методика викладання іноземних мов, (84), 91-98.

8. Шнуровська Л. Лінгвоментальна сутність і класифікація видів праймінга. Science and Education a New Dimension. Philology, VI(44), Issue: 151, 2018.

\section{References:}

1. Bandura A., Dorothea Ross, Sheila A. Ross (1961). Vpervye opublikovano v Journal of Abnormal and Social Psychology, 63, 575-582.

2. Berkovic L. Agressiya. Prichiny, posledstviya i kontrol'. M., 2007. $512 \mathrm{~s}$.

3. Bidenko A. Tehnologiya praimingu v diï. Ukraïns'ka pravda.Blogi. 26.04.2011. https://blogs.pravda. com.ua/ authors/ bidenko/ 4db6904b57e44/

4. Braiant Dj., Tompson S. Osnovy vozdeistviya SMI.: Per. s angl.M., 2004. 432 s.

5. Vinterhoff-SHpurk P. Mediapsihologiya. Osnovnye principy. H., 2016, $268 \mathrm{s.}$

6. Haritonov O. Pro efektivnii sposib manipulyaciï svidomistyu. 30 listopada 2018. https://tokar.ua/read/29332

7. SHamaeva YU. Praiming ta defokusuvannya u lingvokognitivnii reprezentaciï intersemiotichnogo kontinuuma kategorii EMOTIONS. Visnik HNU imeni V. N. Karazina. Seriya: Inozemna filologiya. Metodika vikladannya inozemnih mov, (84), 91-98.

8. SHnurovs'ka L. Lingvomental'na sutnist' i klasifikaciya vidiv praiminga. Science and Education a New Dimension. Philology, VI(44), Issue: 151, 2018.

\section{Novytskyi O. O. Concepts of application of media priming and trigger in political life}

The article is aimed at consideration and study of such media tools as priming and trigger. There are many questions about the patterns of influence of the information array on society, on political life. The analysis of the researches presented in the literature reveals that the theoretical scientific interest is not active enough in Ukraine.

Direct attention is paid to the use of these tools in political life, in political advertising and so on. At the present stage, the model of priming is actively used in cognitive research, which makes it possible to track the effect of prime on cognitive reality. It is interesting and promising to study the local effects of the influence of unconscious information on the effects of awareness in political life. However, so far political 
science has not reached definitive conclusions about the dependence of the priming effect on political consciousness, political choice, and so on.

The article presents the definition of political priming and trigger, discusses problematic issues and settings. Special attention is paid to the distinction between the concepts of "priming" and "priming effect". It is determined that the effect of priming is active in political life, in particular, in political advertising. Virtually every political actor wants to influence the process of activating the voter's memory. The theory of political media priming focuses on how an individual perceives political information received from the media.

An important additional element of the priming process is the use of triggers. The need for triggers is due to the need to analyze events that are not directly related to politics, but can be interpreted in a political way.

Key words: priming, trigger, mass media, politics, society, political advertising, political priming, political trigger. 